\section{Nursery Worker Turnover and Language Proficiency}

Hannah M. Mathers ${ }^{1,11}$ and Alejandra A. Acuña ${ }^{2}$

Department of Horticulture and Crop Science, The Ohio State University, 2001 Fyffe Court, Columbus, OH 43210

Donna R. Long ${ }^{1}$

Department of Spanish and Portuguese, The Ohio University, Columbus, OH 43210

Bridget K. Behe ${ }^{3}$

Michigan State University, Department of Horticulture, East Lansing, MI 48824-1325

Alan W. Hodges ${ }^{4}$

Department of Food and Resource Economics Department, University of Florida, Gainesville, FL 32611-0240

John J. Haydu

Plant First Resources, LLP, Apopka, FL 32703-8504

Ursula K. Schuch ${ }^{5}$

Department of Plant Sciences, University of Arizona, Tucson, AZ 85721-0036

Susan S. Barton ${ }^{6}$

Plant and Soil Sciences, University of Delaware, Newark, DE 19716-2103

Jennifer H. Dennis ${ }^{1}$

Departments of Horticulture and Landscape Architecture and Agricultural Economics, Purdue University, West Lafayette, IN 47907

Brian K. Maynard ${ }^{7}$

Department of Plant Science, University of Rhode Island, Kingston, RI 02881

Charles R. Hall ${ }^{8}$

Department of Horticultural Sciences, Texas A\&M University, College Station, TX 77843-2133

Robert McNeil ${ }^{9}$

Department of Horticulture, University of Kentucky, Lexington, KY 40546-0091

Thomas Archer ${ }^{10}$

The Ohio State University, Columbus, OH 43210

Additional index words. nationality, labor retention, Hispanic, Spanish, training, resources, education, work experience

Abstract. The U.S. nursery and landscape industry generates 1.9 million jobs and had an
annual payroll of greater than $\$ 3$ billion in 2002 , yet little is known about nursery and
landscape workers. This lack of information is even more pressing considering that labor
generally accounts for greater than $40 \%$ of production costs and $31 \%$ of gross sales. Labor
shortages, immigration reform, and legal status of employees are widely reported as the
industry's most critical issues. We hypothesized that relevant data regarding the nursery
industry workforce may raise an appreciation of the industry's diversity, increase
political power and public awareness, and help stakeholders evaluate policy decisions
and plan corrective strategies in a more informed manner. A total of 4466 self-
administered questionnaires were sent in 2006 , attempting to reach 30 nurseries in each
of nine states with 1561 returned (35\% response rate). Hispanics constituted $70 \%$ of the
average nursery workforce, including general laborers $(76 \%)$, crew leaders $(61 \%)$, and
sales/managers (others) (21\%). Across firms, labor retention was less than $51 \%$ after 5
years and only $22 \%$ of employees understood English, raising questions regarding
availability and access to training. Sixty percent of nursery employees had not received
work-related training, although $81 \%$ of men and $72 \%$ of women were interested, and an
association between training and employee retention existed. The highest rated training
topic of interest was English/Spanish (respective of Spanish/English primary language
respondents). There was a positive correlation between developing fluency and worker
turnover, making the laborer attrition rate even more unfavorable for employers who not
only lost employees with acquired experience, but also with acquired English skills.

HortScience Vol. 45(1) JANUARY 2010
The nursery and landscape (Green) industry in the United States contributes \$147.8 billion $(\mathrm{Bn})$ to the national economy and generates 1.9 million (Mn) jobs (Hall et al., 2005 ) with an annual payroll of greater than \$3 Bn (U.S. Census Bureau, 2002). The Green Industry is one of the fastest growing sectors in the nation's agricultural economy, often experiencing growth and expansion in periods of severe financial stress for other agricultural sectors. Recently, the growth in sales has slowed to a rate that indicates the industry may be maturing. Mature markets are those in which the rate of growth in sales is declining. Mature markets require innovative ways to rejuvenate and advance. In an industry in which labor costs account for greater than $40 \%$ of production costs and $31 \%$ of gross sales, innovations with the greatest gain might likely occur in labor use and performance. However, few formal workforce studies have been conducted in this industry. The nine states that participated in this study represent the broad economic and geographic scope of the U.S. nursery industry in terms of national rankings by nursery production sales and growing regions (Table 1). The only major U.S. nursery production region not represented was the $\mathrm{Pa}$ cific. The project team consisted of nine agricultural economists and horticulturists who are members of the S-1021 multistate regional research project entitled "Technical and Economical Efficiencies of Producing, Marketing, and Managing Environmental Plants." Unfortunately, a willing Pacific region collaborator could not be identified. The labor impact of the nursery/landscape industry is greatest in the Eastern region (Hall et al., 2005); therefore, lack of Pacific representation is less significant in this labor survey compared with a survey of nursery sales or production practices.

The Economic Research Service of the U.S. Department of Agriculture (USDA) (USDA-ERS) collects data from The National Agricultural Workers Survey (NAWS), The Current Population Survey, The Farm Labor Survey, and The Census of Agriculture/National Agricultural Statistics Service regarding the agricultural workforce (ERS, 2006). Therefore, some limited labor use data are available on demographics and employment characteristics for the agriculture industry. However, the only survey collecting demographic data regarding the nursery industry workforce specifically were conducted in Oregon and Ohio. These surveys determined that $90 \%$ and $60 \%$, respectively, of the workforce was Hispanic (Mathers, 2003). Currently, production-level labor is presumed to be predominantly Spanish-speaking; however, few formal studies exist to support this assumption. In discussions with ornamental economists on the S-1021 committee, it was determined that no national nursery workforce surveys had been conducted regarding the workforce demographics or means of improving worker productivity and retention. This lack of information was critical considering: 1) $31 \%$ of gross sales (American Nurseryman, 
Table 1. Total number of nurseries (clusters) by state (strata), region, and national ranking by sales included in survey of the nursery employees (observation units). ${ }^{\mathrm{z}}$

\begin{tabular}{|c|c|c|c|c|c|c|c|c|c|c|}
\hline State & Region & $\begin{array}{l}\text { National } \\
\text { ranking and } \\
\text { sales value }\end{array}$ & $\begin{array}{c}\text { Total } \\
\text { nurseries } \\
\text { (t) }\end{array}$ & $\begin{array}{c}\text { Nurseries } \\
\text { mailed } \\
\text { packets }(\mathrm{m})\end{array}$ & $\begin{array}{l}\text { Nurseries } \\
\text { returning } \\
\text { packets }(\mathrm{p})\end{array}$ & $\begin{array}{c}\text { Nursery } \\
\text { packet response } \\
\text { rate }(\mathrm{p} / \mathrm{m})(\%)\end{array}$ & $\begin{array}{c}\text { Observation } \\
\text { unit (employee) } \\
\text { wt }(\mathrm{t} / \mathrm{p})\end{array}$ & $\begin{array}{c}\text { Surveys } \\
\text { sent to } \\
\text { employees (s) }\end{array}$ & $\begin{array}{c}\text { Surveys } \\
\text { returned from } \\
\text { employees (r) }\end{array}$ & $\begin{array}{c}\text { Survey } \\
\text { response } \\
\text { rate }(\%)(\mathrm{r} / \mathrm{s})\end{array}$ \\
\hline Florida & Southeast & Second \$1.84 Bn & 7703 & 30 & 20 & 66.7 & 385.15 & 950 & 372 & 39.2 \\
\hline Indiana & Midwest & 24 th $\$ 187,000$ & 437 & 10 & 3 & 30.0 & 145.67 & 184 & 28 & 15.2 \\
\hline Michigan & Midwest & Sixth $\$ 628 \mathrm{Mn}$ & 1525 & 12 & 6 & 50.0 & 254.17 & 239 & 122 & 51.0 \\
\hline Ohio & Midwest & Seventh \$464 Mn & 1434 & 32 & 23 & 72.0 & 62.35 & 1569 & 395 & 25.2 \\
\hline Delaware & Northeast & 45 th $\$ 22,000$ & 131 & 10 & 10 & 100.0 & 13.1 & 1100 & 316 & 28.7 \\
\hline $\begin{array}{l}\text { Rhode } \\
\text { Island }\end{array}$ & Northeast & 39th $\$ 37,000$ & 87 & 2 & 2 & 100.0 & 43.5 & 150 & 33 & 22 \\
\hline Tennessee & Southern & 15 th $\$ 282 \mathrm{Mn}$ & 1383 & 23 & 7 & 30.4 & 197.57 & 274 & 36 & 13.1 \\
\hline Kentucky & Southern & 29th $\$ 96,000$ & 389 & 4 & 4 & 100.0 & 97.25 & 100 & 33 & 30.6 \\
\hline Arizona & Southwest & 14th $\$ 284 \mathrm{Mn}$ & 243 & 20 & 6 & 30.0 & 40.5 & 737 & 226 & 28.7 \\
\hline Totals & & & & 143 & 71 & & & 4466 & 1561 & 34.9 \\
\hline
\end{tabular}

${ }^{z}$ Nurseries were contacted by phone from a random sample drawn of 40 nurseries/state, until 30 firms or what was practical in each, agreed to participate, sometimes requiring multiple drawings of 40 to find enough to participants. Nurseries agreeing to participate were mailed packets (m) containing English and Spanish surveys in accordance with the numbers specified by the employer. Participating nurseries were those that returned the packets ( $\mathrm{p}$ ) and $\mathrm{p} / \mathrm{m}$ was the percent nursery packet response rate. Total numbers of surveys sent to employees, returned, observation response rate, and calculated weighting of observation unit are presented.

$\mathrm{Bn}=$ billion; $\mathrm{Mn}=$ million.

2008) go to labor; 2) labor shortages resulting from the expiration of the H2-B Returning Worker Exemption and the capping of $\mathrm{H}-2 \mathrm{~B}$ to 60,000 in 2008 (Landscape Management Staff, 2007); 3) the lack of viable immigration reform policies (Neal, 2007); and 4) the uncertain legal status of employees given the recent Social Security No-match Rule (Pacific Coast Nurseryman and Garden Supply Dealer Staff, 2007). Data of the nursery industry workforce are long overdue considering such data may raise appreciation of the industry's diversity, increase political power and public awareness, help stakeholders evaluate policy decisions, and plan corrective strategies.

Received for publication 23 Apr. 2009. Accepted for publication 19 Oct. 2009.

Salaries and research support provided by state and federal funds appropriated to The Ohio Agricultural Research and Development Center; Horticulture and Crop Science Department, The Ohio State University; The Horticultural Research Institute, Washington, DC; and the Ohio Nursery and Landscape Association, Westerville, $\mathrm{OH}$.

Manuscript number HCS 09-08. This was a project of the Green Industry Consortium (S-1021 Multistate Research Committee a group of agricultural economists and horticulturists in the United States. We acknowledge the technical assistance of Drs. Claudio Pasian, Alice Black, Luke Case, and Cheryl Cuthbert of The Ohio State University and the support of the anonymous nursery owners and staff that participated in this study. This paper is dedicated in memory of Dr. John Brooker, former Professor Emeritus, Department of Agricultural Economics, University of Tennessee, Knoxville, TX.

${ }^{1}$ Associate Professor.

${ }^{2}$ Former graduate student.

${ }^{3}$ Professor.

${ }^{4}$ Extension Scientist.

${ }^{5}$ Associate Specialist.

${ }^{6}$ Assistant Professor.

${ }^{7}$ Professor.

${ }^{8}$ Professor and Ellison Endowed Chair for International Floriculture.

${ }^{9}$ Professor (retired).

${ }^{10}$ Associate Professor, Extension.

${ }^{11}$ To whom reprint requests should be addressed; e-mailmathers.7@osu.edu.
The nursery industry is, as are all agricultural sectors, labor-intensive. In agriculture, $40 \%$ to $70 \%$ of production costs are related to labor (Billikopf, 2006). This cost is much higher than for other manufacturing sectors. Some nurseries report that approximately two-thirds of their annual expenses are related to labor (Studebaker Nurseries, New Carlisle, $\mathrm{OH}$, personal communication). The industry's heavy reliance on labor and the need to provide technical information to workers for advancement opportunities are evident. The U.S. nursery and landscape industry is a maturing industry with average growth rates slowing from 14\% (1970s), 10\% (1980s), $5 \%(1990 \mathrm{~s})$ to $3 \%(2000 \mathrm{~s})$ (Hall et al., 2005). When an industry is maturing, new innovative ways to "grow the industry" are required. It follows that innovations with labor in such a labor-intensive industry could have more profound impacts than any other modernization.

We had two objectives with this article: 1) to determine the nationality, primary language, and work activities of the nursery industry worker; and 2) to assess the benefits, technical information needs, and learning/training/resources available between workers of different cultural and language backgrounds. There were many other objectives and survey findings not related to language and labor retention that are reported in Acuña et al. (unpublished data).

\section{Materials and Methods}

A self-administered questionnaire (SAQ) was written in English with input from S-1021 collaborators in the states of Michigan, Delaware, Tennessee, Florida, Indiana, Kentucky, Arizona, and Rhode Island with consideration to project objectives and limiting bias for the target audience. A Spanish translation of the SAQ was completed by A. Acuña and certified by Dr. D. Long, Associate Professor, Department of Spanish and Portuguese at The Ohio State University (OSU), Columbus, $\mathrm{OH}$. A field test of the Spanish SAQ was administered to nine Hispanic employees at a central Ohio nursery. A focus group was also conducted, after the SAQ was administered, to probe respondents' understanding and general impressions of the survey questions according to Tourangeau et al. (2006) and Mathers and Acuña (2008). Required permission to collect human subject data using the anonymous, voluntary, mailed survey was obtained from the OSU Office of Responsible Research Practices [2006, Institutional Review Board (IRB), Aug. 2005]. IRB approval was also obtained in the seven other states between Fall 2005 and Spring 2006. The final version of the SAQ contained 31 questions (139 variables). This article focuses on the descriptive statistics (analysis of frequencies, SES, and 95\% confidence intervals) of 42 of the 139 variables with seven of those also tested for association with labor retention using the Rao Scott $\chi^{2}$ (RSCS). Acuña et al. (2010) reports findings on 41 of the remaining 97 variables.

A nursery for the purpose of this study was defined as a place of ornamental plant (annuals and perennials) production, excluding Christmas trees, with at least one paid full-time employee, not including the nursery owner, and sampling and observation units being the nursery (cluster) and the employee, respectively. A stratified, clustered, random sample of 40 nurseries in each state, 20 medium (5 to 19 acres) and 20 large (greater than 20 acres) including nursery contact name, address, and telephone number was drawn by researchers at OSU, Columbus, $\mathrm{OH}$, from the sample frame developed for an economic impact study of the green industry (Hall et al., 2005), which contained 38,269 U.S. nurseries classified by state and acreage and sent by e-mail from OSU to researchers in various states according to Acuña et al. (2010).

Nurseries were called to participate using a standardized script developed at OSU stating, "...we would like to send the survey to be distributed to your employees, holding full time or part-time positions, migrant or seasonal, crew leader or forepersons but excluding anyone considered managerial level" according to Acuña et al. (2010). In most 
states, several random samples had to be drawn, sent, and called before 30 cooperating sites were identified.

Data entry was conducted using the statistical and data management package SPSS (SPSS.com ${ }^{\circledR}$ 2006; SPSS Inc. Chicago, IL) Version 15. Data were analyzed using SAS ${ }^{\circledR}$ Version 9.1 (SAS Institute Inc., Cary, NC) for Windows using variance estimates based on the multistage survey design with stratification, clustering, and unequal weighting (SAS Institute Inc., 2002-2003). Sampling weights (the inverse of the probability of selection) were required to manage stratification effects and clustering on point estimates. In each state, the observation unit (employee) weight was calculated by dividing the total number of nurseries by the number of participating nurseries (Table 1).

Missing values were calculated and replaced with their predicted values for noresponse items using SPSS ${ }^{\circ}$ linear trend point imputation (Lohr, 1999). Overall response rates by state were calculated using the American Association for Public Opinion Research guidelines (AAPOR, 2007) in which the weighted sum of the surveys received is divided by the weighted sum of the surveys sent. An analysis of one-way to n-way frequencies and crosstabulation tables, including estimates of population totals and proportions, corresponding SES, and $95 \%$ confidence intervals (or $P=0.05$ ), was conducted by question using PROCSURVEYFREQ (SAS Institute Inc., 2002-2003). To test association between variables, the RSCS test in SAS Institute Inc. (2002-2003), a designadjusted version of the Pearson $\chi^{2}$, which takes into account survey design and provides inferences for the entire study population and an $\mathrm{F}$ value, was performed. The null hypothesis for two-way tables with the RSCS test is "no association between the row and column variables" (SAS Institute Inc., 2002-2003).

\section{Results and Discussion}

More than 3000 phone calls were conducted in nine states to arrange for the mailing of 4466 surveys with 1561 returned (Table 1), representing a $35 \%$ survey response rate $(75 \%$ and $25 \%$ Spanish and English, respectively). In several states, a sample of 30 was never reached (Table 1). Florida and Ohio represented the only states where 30 packets were mailed (Table 1). Many nurseries contacted by phone did not want to participate in the study. Acuña and Mathers (2009) also identified employer indifference and reluctance to participate in programs dealing with Hispanic nursery employees. Response rates by state (surveys returned/surveys sent) varied from $13 \%$ in Tennessee to $51 \%$ in Michigan (Table 1). There is no consensus regarding acceptable response rates for mailed surveys and, according to Lohr (1999), giving absolute guidelines for acceptable response rates is dangerous and can lead to complacency. Of nurseries contacted in Florida, a total of $67 \%$ returned surveys to OSU (Table 1). Seventy- two percent of the nurseries contacted in Ohio returned surveys (Table 1). Rhode Island and Delaware had fewer nurseries to survey, 87 and 131, respectively (Table 1), and few that met the size restriction of the study. In these states, researchers visited nurseries and administered the surveys onsite resulting in a $100 \%$ nursery packet response rate. The response rates (returned/ sent) were $22 \%$ and $29 \%$ for Rhode Island and Delaware, respectively. A $25.2 \%$ response rate in Ohio (Table 1) was lower than the nursery response rate reported by Mathers (2003) of 52\% conducting an on-site survey. However, the nursery contacted/response rate in Ohio of $72 \%$ (Table 1) was higher than the Mathers (2003) study.

High employee turnover. Hispanics constituted $70 \%$ of the average nursery workforce, including general laborers $(76 \%)$, crew leaders $(61 \%)$, and sales/managers (others) (21\%) (Acuña et al., 2010); a significant correlation existed between time working in the nursery industry with current job position (RSCS, $P<0.0001$ ). The polynomial correlation $r=0.8478$ was only significant for the laborer level. Corresponding polynomial correlation coefficients $(r)$ for crew leader and other job positions were $r=0.4991$ and 0.6801 , respectively, as calculated by Excel (Microsoft Inc., Redmond, WA). Comparing type of job (general laborer, crew leader, or other) and number of years working, at the laborer level, the turnover rate was more than $51 \%$ after 5 years of employment [37\% ( 0 to 5 years $)$ to $18 \%(5$ to 10 years $) / 37 \times 100)$ ] (Fig. 1). The highest worker turnover rate in the United States is in the accommodation and food services sector at 56\% (Nobscot Corp., 2006). At more than 51\%, the nursery industry ranks second only to this traditionally unstable employment industry. With an estimated cost of $\$ 4000$ to $\$ 7000$ to replace an hourly worker (Lousberg, 2005), efforts to stabilize the nursery industry workforce are crucial to secure the industry's economic survival. Additionally, in Ohio, where the nursery/landscape industry is one of the largest employers, surpassed only by Florida, California, and Texas in terms of worth contributed to the state's economy (Hall et al., 2005), improved economic stability for the industry would translate into economic stability for the entire state. The high worker turnover rate was limited to the laborer level. The majority of crew leaders and others (sales, managers, and so on) were working longer than 10 years and many working longer than 15 years (Fig. 1). The indifference associated with obtaining employers to participate in this survey and lack of employer participation in other labor force programs conducted by OSU 2003-2006 (Acuña and Mathers, 2009 ) indicate major outreach efforts are required at the managers/owner level to reduce apathy and increase sensitivity to issues of the current labor supply.

Salary is often noted as the most important issue for nursery workers, especially with migrant laborers; however, in this survey, "lack of benefits" received the highest response rate $(87 \%)$ when "very" important and "somewhat" important categories were totaled versus $81 \%$ for "low salary." DaleOlsen (2006) also noted a positive correlation existed between higher wages and benefits and reduced worker turnover. Job accidents, as the second "very" important issue (Fig. 2), agrees with Yeoman (2000), which indicates immigrant workers often perform dangerous jobs and/or jobs requiring repeating the same action continuously for hours in high temperatures, causing development of carpal tunnel syndrome or back injuries that require returning home and/or surgery to correct. The rating of job accidents (second) and lack of benefits (fourth) as "very" important would be related issues to an employee (Fig. 2). Coupled together, these factors reduce earning potential, negating the main reason stated for seeking U.S. employment: increased remuneration.

Issues deemed to be "not important" included "no job continuity" and "work not challenging" (Fig. 2). However, the question asking about job continuity (lack of yearround employment) also had the highest level of responses in the "somewhat" important category and marked the only time "somewhat" important positively outmeasured the "very" important category (Fig. 2). This possibly indicates if other issues such as job safety, salary, and so on were corrected, lack of year-round employment would be more important to the employee. This is pertinent because many nursery owners have indicated they would like to retain workers for yearround employment but cannot convince employees to stay. Migrant workers have discovered how they can extract wealth from nursery operations on a short-term basis, maintain home bases in Mexico and elsewhere, and leave their options open for future employment. They, therefore, contribute to the high worker turnover observed in this study.

Country of origin. Seventy percent of survey respondents were born outside the United States, including $57 \%$ in Mexico, $5 \%$ in Guatemala, 3\% in Puerto Rico, and $5 \%$ elsewhere (Acuña et al., 2010). Sixty-five percent of the Mexican workers filled general laborer positions and 48\% held crew leaders positions (Fig. 3). Seventy percent of the "other" job classification was filled by U.S. native-born employees. Responses in the "elsewhere" classification included mainly other Hispanic countries such as Venezuela, Colombia, Panama, Dominican Republic, Paraguay, El Salvador, Ecuador, and Chile. These results are similar to those reported in NAWS (U.S. Department of Labor, Employment and Training Administration, 2002) in which $78 \%$ of all crop workers were born outside the United States. According to Mosisa (2002), the ethnic and racial composition of the U.S. workforce is diversifying at a rapid pace. Much of that change reflects the proportion foreign-born workers versus U.S. native-born workers. In 1960, this proportion was $1: 17$; today the proportion is $1: 8$. Additionally, the birth country of these workers 


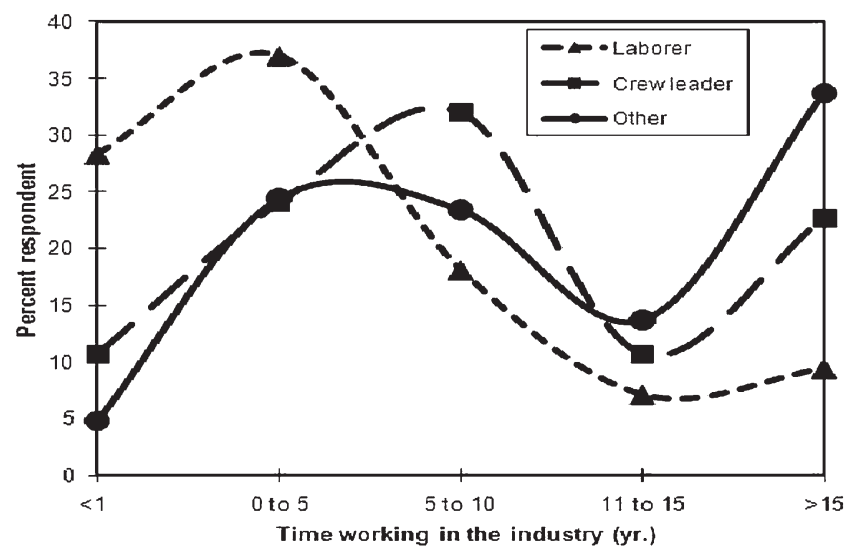

Fig. 1. Survey responses from nine states and 1561 respondents indicated a significant correlation existed between times working in the nursery industry with current job position (Rao-Scott $\chi^{2}, P<0.0001$ ). The polynomial correlation $r=0.8478$ was only significant for the laborer level. Corresponding polynomial correlation coefficients $(r)$ for crew leader and other job positions were $r=0.4991$ and 0.6801, respectively, as calculated by Excel (Microsoft Inc., Redmond, WA).

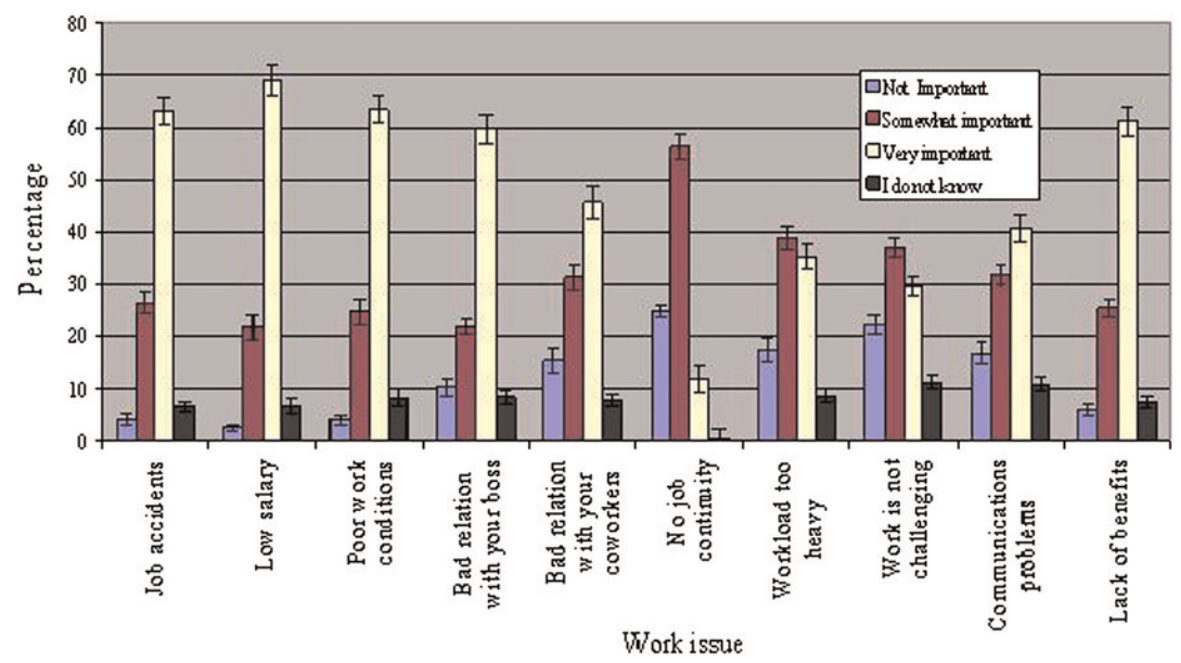

Fig. 2. Survey responses from nine states and 1561 surveys indicating nursery employee work-related issues in terms of importance, percentages, and ses by issue; calculations based on survey design and weights.

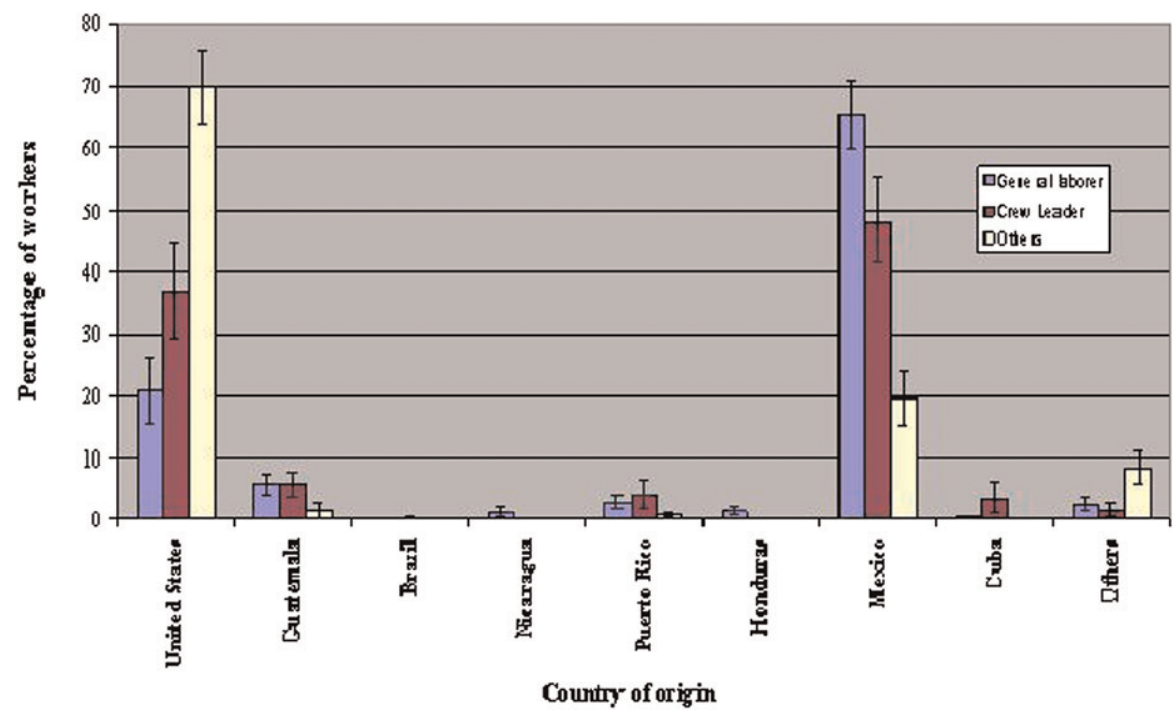

Fig. 3. Survey responses from nine states and 1561 surveys showing the relationship of nursery job position to country of origin, percentages, and se calculations based on survey design and weights. has shifted. In $1960, \approx 75 \%$ of the foreignborn labor force came from Europe. Today, European workers represent less than $16 \%$, largely reflecting the influx of immigrants from Latin American and Asian countries. In 1965, the Immigration and Nationality Act was passed, eliminating quotas for national origin, race, or ancestry. This has allowed a large influx of immigrants from Mexico, Philippines, India, China, Cuba, El Salvador, Vietnam, South Korea, Canada, and the Dominican Republic (Mosisa, 2002). In 2000, people of Mexican origin were the largest Hispanic group in the United States representing $59 \%$ of the U.S. total Hispanic population (Ramirez, 2004).

Advancement and language. The primary language spoken at work by survey respondents was Spanish (63\%) followed by English $(30.3 \%)$, whereas only $6 \%$ of the workers indicated an ability to speak English and Spanish and a very small percentage $(0.1 \%)$ indicated they could speak another language such as Mixteco or Portuguese. These language responses were similar to those reported in NAWS (U.S. Department of Labor, Employment and Training Administration, 2002), in which $80 \%$ of the workers indicated Spanish was their primary language, $18 \%$ English, and $2 \%$ other. There was no report of language spoken at work in the 2000 U.S. Census. However, the Census did report that $75 \%$ of Hispanics spoke a language other than English at home with $99 \%$ of those speaking Spanish (U.S. Census Bureau, 2002).

A significant association was found between job position and ability to speak (RSCS $=106.7, \mathrm{~F}=13.4, P<0.0001)$, understand (comprehend) (RSCS $=172.2, \mathrm{~F}=$ 21.7, $P<0.0001$ ), and read (interpret) English $(\mathrm{RSCS}=123.9, \mathrm{~F}=15.5, P<0.0001)$. Fifty-seven percent of laborers reported "no English"-speaking ability (33\%) or "a few words" (24\%) (Table 2). By contrast, $22 \%$ of crew leaders and $14 \%$ of others reported "no English"-speaking ability or only "a few words" (Table 2). The percentages obtained were lower for "I speak no English" (33\%) compared with NAWS (U.S. Department of Labor, Employment and Training Administration, 2002) in which $44 \%$ of the crop workers said, "They could not speak English." This difference may be the result of workers in the nursery industry having more time and exposure to English and technical terms. The nursery workforce is not as "seasonal" as in other agricultural sectors such as fruit or vegetable production in which significant worker numbers are needed only for short periods of 1 or 2 months, coinciding with harvests. In the nursery sector, workers are employed on average 6 months with many staying for 10 months (Mathers, 2003). In a survey of low-skilled immigrants, Chiswick (1991) found that verbal and comprehension fluency increased with duration in the United States. He also observed the greatest increase duration was for those who had more schooling in their home country in all groups except Hispanics. Our results concur with Chiswick (1991) because no 


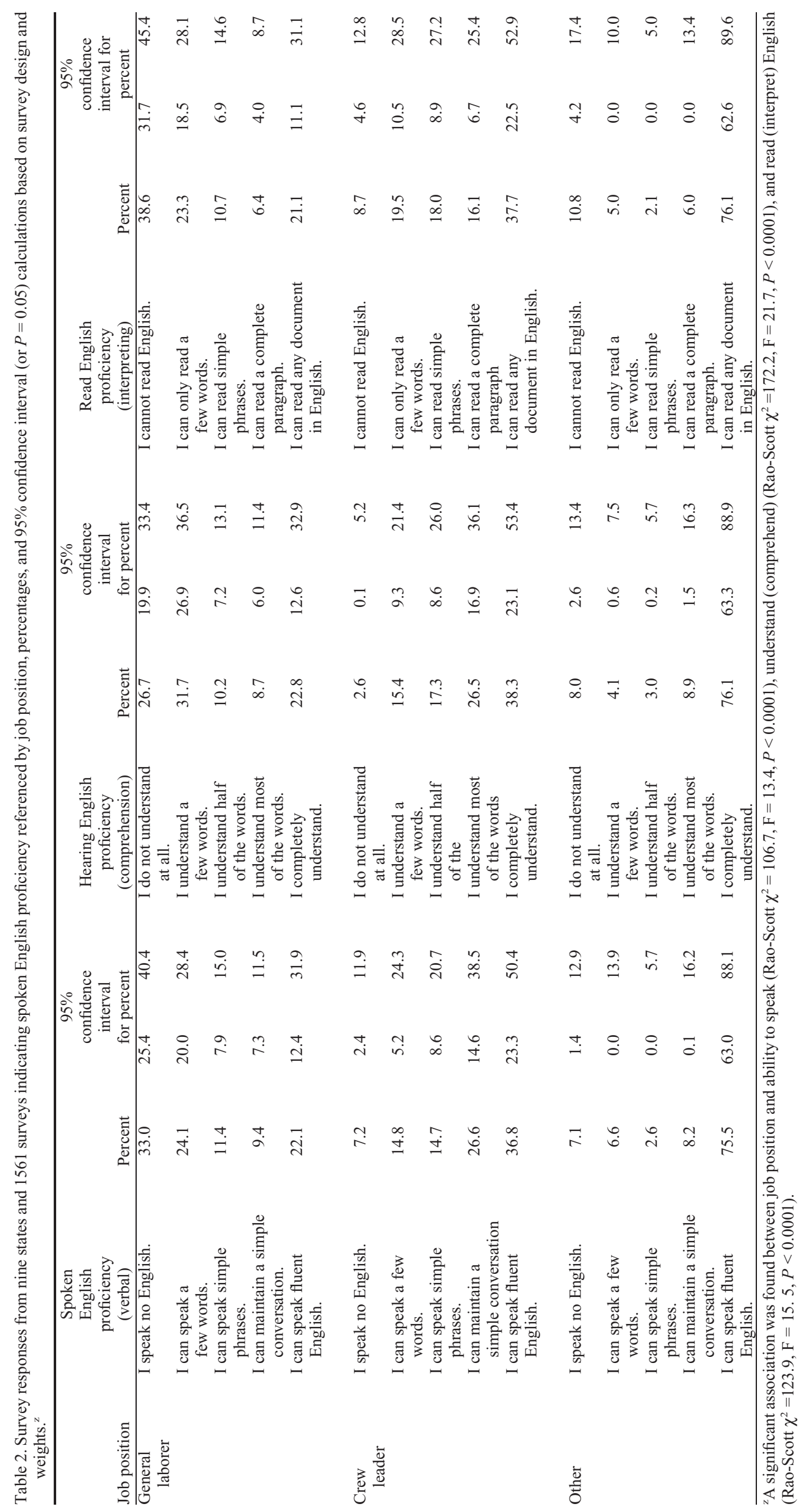


relationship between previous education level and language skill development was ascertained (data not shown).

Skill development. There were several other important findings from the survey questions regarding language in relation to skill development, interest, and employee turnover. A difference in comprehension, verbal, and reading skill development was evident with job position. Ranked from highest to lowest (a negative response question), comprehension $\rightarrow$ verbal $\rightarrow$ reading skills were $26.7 \%, 33 \%$, and $38.6 \%$ and $2.6 \%, 7.2 \%$, and $8.7 \%$ for general laborers and crew leaders, respectively (Table 2). This finding that verbal skills are lagging behind comprehension (understanding English by Spanish speakers) (Table 2) is consistent with the "preproduction period" of second language acquisition or "the silent period" as defined by Haynes (2008). A large body of literature supports this "silent period" hypothesis (Krashen, 1987, 1988). The silent period varies in duration because a newcomer is unwilling to speak in the second language. Nearly all students go through a silent period. This stage can last for as long as 1 year (Haynes, 2008).

In the "early production phase" or second phase of second language acquisition (Haynes, 2008), general laborers are still indicating greater comprehension of English ["I understand a few words" $(31.7 \%)$ ] than ability to speak ["I speak a few words" (24.1\%)] (Table 2 ). Most researchers support that the natural language acquisition order is for listening/ comprehension to develop before speaking (Krashen, 1987, 1988). The early production phase may last up to 6 months during which time students develop a receptive and active vocabulary of $\approx 1000$ words and can usually speak in one- or two-word phrases. They can use short language chunks that have been memorized, although these chunks may not always be used correctly.

"Speech emergence" is the third phase of second language acquisition (Haynes, 2008). At this stage, students develop a vocabulary of $\approx 3000$ words and can communicate with simple phrases and sentences. General laborers at this phase are indicating an equal ability to comprehend English ["I understand half of the words" (10.2\%)] as to speak ["I can speak simple phases" (11.4\%)] (Table 2). This equivalency would be unusual but not without precedence. An Army Specialized Training Program (World War II) used verbal drills based on behavioral psychology theory to train solders to deliver specific types of messages (such as troop locations) in a second language. They were able to perform very well within a narrow context but had very little listening comprehension in general and no speaking ability in unfamiliar contexts (Agard et al., 1945). People who volunteer in second language clinics have observed nonnative speakers may understand and function effectively within the narrow context of their tasks; however, their ability to function is not indicative of their overall English proficiency. To potentially earn more money and advance in the workplace, general laborers may feel external pressure to increase their verbal skills beyond their comprehension. This finding is of interest because many nursery employers feel that if their staff can speak English, they can understand English and therefore they can conduct technical training sessions in English versus Spanish.

The phase of second language acquisition, in which crew leaders make the greatest gain in verbal and comprehension skills versus laborers, is in the "intermediate fluency" or the fourth stage (Haynes, 2008). This fourth stage was evaluated in our survey with the questions, "I can maintain a simple conversation" (26.6\% crew leaders; 9.4\% laborers) (Table $2)$. At this stage, English language learners have a vocabulary of 6000 active words and the ability to speak and comprehend is near equivalent (Haynes, 2008) consistent with our findings. However, employers should be aware that even crew leaders are far from mastering the fifth stage or "advanced fluency" in English as described by Haynes (2008). In fact, crew leader verbal and comprehension fluency is only $15 \%$ ( $36.8 \%$ to $22.1 \%$ and $38.3 \%$ to $22.8 \%$, respectively) (Table 2 ), respectively, more than general laborers.

Employee turnover and training. Another important finding from the language question responses dealt with the association of language development and worker turnover and the consequences of this for worker training. Haynes (2008) indicated it takes second language students 4 to 10 years to achieve the fifth stage or "advanced fluency." This is interesting because $51 \%$ of the laborers leave after 5 years and only 5\% remain employed after 10 years. There seems to be a relationship between developing fluency and worker turnover. Of course, this makes the worker attrition even more unfavorable for employers. Employers not only lose all the tacit knowledge, technical training, and company familiarity that employees may have acquired over 5 years, but they also lose employees who have attained advanced verbal and comprehension skills, making them the kind of employees they want to retain and advance. Haynes (2008) indicates that students at this stage will be near native in their ability to perform in content area learning.

Training is known to play a significant role in employee retention, advancement, increased remuneration, and productivity (Witty, 2007). Mexican and other Hispanic immigrants have significantly lower levels of education than any other American groups, including their American native-born counterparts. Therefore, an- other potential benefit of employee training might be to reduce the educational gap for Hispanic nursery employees. A recent study with migrant workers in Alabama's horticultural industry indicated a $1 \%$ increase in a firm's total number of employees raised gross sales by $0.69 \%$ (Bellenger et al., 2008) indicating migrant employees are one of the most success means of increasing company productivity. This finding also was supported by Posadas et al. (2006) in which hiring an additional full-time-equivalent increased annual sales by $\$ 69,513$ versus a $1 \%$ increase in mechanization (\$3384/year) or adding one more acre in production (\$1207/year).

Sixty percent of nursery employees surveyed had not received work-related training and if training was provided, it was most often delivered in English (data not shown). Although $81 \%$ of men and $72 \%$ of women were interested in training (Table 3), and an association between training and employee retention existed, training in the majority of nurseries did not occur. The highest rated training topic of interest was English/Spanish regardless of gender (respective of Spanish/ English primary language) $(75 \%)$ (Table 3$)$. Other topics of interest were plant identification, plant disease identification, and control and equipment safety (Acuña et al., 2010). Seventyeight percent of female respondents and 70\% of males would prefer training in Spanish (Table 3). Only $30 \%$ of men and $22 \%$ of women preferred training in English (Table 3).

We have shown there is a correlation between developing fluency and nursery worker turnover. With $52 \%$ of the laborers leaving after 5 years and only $5 \%$ remaining employed after 10 years, employers not only lose all the technical training and company familiarity that employees have acquired in the past 5 years, but they also lose an employee that has attained advanced verbal and comprehension skills. Previous surveys have indicated employer-provided training opportunities were positively received by Hispanic nursery employees, improved worker/manager relations, and improved company loyalty (Mathers, 2003). Some nurseries report that approximately twothirds of their annual expenses are directly related to labor. With significant slowing in the U.S. nursery industry growth rate, it follows that innovations in labor retention in such a labor-intensive industry could have more profound impacts than any other modernization. Nursery workers are interested in technical classes. Seventy-seven percent of workers (pooled over gender) indicated an

Table 3. Survey responses from nine states and 1561 surveys regarding training interest by gender, desired language of training and training topic of highest interest, percentages, and $95 \%$ confidence interval or $P=0.05$ calculations based on survey design and weights.

\begin{tabular}{lccccccc}
\hline Gender & $\begin{array}{c}\text { Interested } \\
\text { in training }\end{array}$ & Percent & $\begin{array}{c}95 \% \text { confidence } \\
\text { interval for } \\
\text { the percentage }\end{array}$ & $\begin{array}{c}\text { Highest topic } \\
\text { of interest }\end{array}$ & $\begin{array}{c}\text { Percent desire } \\
\text { training in } \\
\text { English }\end{array}$ & $\begin{array}{c}\text { Percent desire } \\
\text { training in } \\
\text { Spanish }\end{array}$ \\
\hline Women & Yes & 72.3 & 65.2 & 79.4 & English & 22 & 78 \\
& No & 27.7 & 20.6 & 35.0 & & & 70 \\
Men & Yes & 80.8 & 76.0 & 85.6 & English & 30 & 70 \\
& No & 19.2 & 14.4 & 24.0 & & & \\
\hline
\end{tabular}


interest in attending training courses. In addition, it was observed in the nurseries visited that the workers are open to learning more. The preferred topic for a course was English (75\%). This finding related to the association of job position and English proficiency. Those with higher English proficiency were obtaining better jobs in the industry. The nursery workers see English as a way to advance economically and professionally and therefore they indicated this was their greatest technical need.

Future studies are needed to evaluate the effects of Hispanic employee training, principally the effects of English training on worker retention. Currently, there are no studies evaluating these effects in the agricultural or horticultural sector. Methods to increase employer/employee relationships are also needed to improve work efficiency.

\section{Literature Cited}

Acuña, A. and H. Mathers. 2009. Implementing and assessing an onsite bilingual educational program for Hispanic nursery workers in Ohio. J. Environ. Hort. 27:91-98.

Agard, F.B., R.J. Clements, W.S. Hendrix, E. Hocking, S.L. Pitcher, A. van Eerden, and H.G. Doyle. 1945. A Survey of language classes in the Army specialized training program. Mod. Lang. J. 29:155-160.

American Association for Public Opinion Research. 2007. Response rate calculator. 3 May 2008. <http://www.aapor.org/rrc.asp>.

Anonymous. 2007. Judges ruling delays social security no-match rule: If established it will be a challenge for green industry employees. Pacific Coast Nurseryman and Garden Supply Dealer 66:12.

Anonymous. 2008. Wage and benefits survey. American Nurseryman 207:11-15.

Bellenger, M., D. Fields, K. Tilt, and D. Hite. 2008. Producer preferences for migrant labor and the wage, hours, and gross sales effects in
Alabama's horticulture industry. HortTechnology 18:301-307.

Billikopf, G. 2006. Agricultural labor management. University of California. 22 May 2008. <http:// www.cnr.berkeley.edu/ucce50/ag-labor/>.

Chiswick, B.R. 1991. Speaking, reading, and earnings among low-skilled immigrants. J. Labor Econ. 9:149-170.

Dale-Olsen, H. 2006. Wages, fringe benefits and worker turnover. Labour Econ. 13:87-105.

Economic Research Service (ERS). 2006. U.S. Department of Agriculture. Floriculture crops: Background. 12 Dec. 2008. <http://www.ers. usda.gov/briefing/Floriculture/Background.htm>.

Hall, C., A. Hodges, and J. Haydu. 2005. Economic impacts of the green industry in the United States. 16 Apr. 2008. <http://www.utextension. utk.edu/hbin/greenimpact.html $>$.

Haynes, J. 2008. Stages of second language acquisition. Everything ESL. 8 Dec. 2008. <http:// www.everythingesl.net/inservices/language_ stages.php>.

Krashen, S.D. 1987. Principles and practice in second language acquisition. Prentice-Hall, New York, NY.

Krashen, S.D. 1988. Second language acquisition and second language learning. Prentice-Hall International Inc., New York, NY.

Landscape Management Staff. 2007. In the know. Countdown to crisis? H-2B extension expires. Landscape Management 46:14.

Lohr, S. 1999. Sampling design and analysis. Duxbury Press, Pacific Grove, CA. p. 221-249.

Lousberg, D. 2005. Here today and here to stay: Evaluating your employee retention program. Last updated Nov. 2008. 23 Nov. 2009. <http://www. carlsbad.org/EditionDetail.aspx?aid=251> .

Mathers, H. 2003. Technical information requested by Hispanic nursery employees survey results from Oregon and Ohio. J. Environ. Hort. 21: 184-189.

Mathers, H.M. and A. Acuña. 2008. Multistate survey of nursery workforce: Ohio, Michigan, Delaware, Tennessee, Florida, Indiana, Kentucky, Arizona and Rhode Island. Implementing and assessing an onsite bilingual education program for Hispanic nursery workers in Ohio. June Educational Update. The Buckeye. June. p. 1-8.

Mosisa, A. 2002. The role of foreign-born workers in the U.S. economy. Mon. Labor Rev. 125:3-14.

Neal, K. 2007. Immigration reform in 2007? Not so much. Nursery Management and Production 23:43-44.

Nobscot Corp. 2006. Retention management and metrics: Latest BLS employee turnover rates for year ending Aug. 2006. Released 11 Oct. 2006. 23 Nov. 2009. <http://www.nobscot.com/ survey/index.cfm>.

Ohio State University (OSU), Office of Responsible Research Practices (ORRP). 2006. 14 Aug. 2008. $<$ http://orrp.osu.edu/humansubjects/education. cfm.http://orrp.osu.edu/humansubjects/irb/ intialreview.cfm>.

Posadas, B.C., P.R. Knight, R.Y. Coker, C.H. Coker, and S.A. Langlois. 2006. Economic impact of technology adoption among horticultural firms. Proc. Southern Nurs. Assoc. Res. Conf. 51:317-320.

Ramirez, R. 2004. We the people: Hispanics in the United States. Census 2000 special reports. Issued Dec. 2004. U.S. Census Bureau.

SAS Institute Inc. 2002-2003. Version 9.1. Cary, NC.

SPSS Inc. 2007. Statistical package for the social sciences. Chicago, IL.

Tourangeau, R., L. Rips, and K. Rasinski. 2006. The psychology of survey response. Cambridge University Press. New York, NY. p. 257.

U.S. Census Bureau. 2002. Census 2000. 23 Nov. 2009. <http://www.census.gov/>.

U.S. Department of Labor, Employment and Training Administration. 2002. The National Agricultural Workers Survey (NAWS). 2 Apr. 2008. $<\mathrm{http}$ ://www.doleta.gov/agworker/report9/toc. cfm>.

Witty, J. 2007. Retention, the hidden benefit of training. Vault.com. 23 Nov. 2009. <http://www. vault.com $/$ nr/newsmain.jsp?nr_page $=3 \&$ ch_ id=402\&article_id=19361\&cat_id=1123>.

Yeoman, B. 2000. Hispanic Diaspora. Mother Jones. 10 May 2008. <http://www.motherjones.com/ news/feature/2000/07/diaspora.html>. 